BORN IN THE USA 
This page intentionally left blank 


\section{BORN IN THE USA HOW A BROKEN MATERNITY SYSTEM MUST BE FIXED TO PUT MOTHERS AND INFANTS FIRST}

\section{MARSDEN WAGNER, MD, MS}

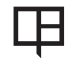


University of California Press, one of the most distinguished university presses in the United States, enriches lives around the world by advancing scholarship in the humanities, social sciences, and natural sciences. Its activities are supported by the UC Press Foundation and by philanthropic contributions from individuals and institutions. For more information, visit www.ucpress.edu.

University of California Press

Berkeley and Los Angeles, California

University of California Press, Ltd.

London, England

(C) 2006 by The Regents of the University of California

Library of Congress Cataloging-in-Publication Data Wagner, Marsden, 1930-.

Born in the USA : how a broken maternity system must be fixed to put mothers and infants first / Marsden Wagner.

p. $\quad \mathrm{cm}$.

Includes bibliographical references and index. ISBN-I3: 978-0-520-24596-9 (cloth : alk. paper) ISBN-IO: 0-520-24596-2 (pbk. : alk. paper)

I. Obstetrics-United States. 2. Childbirth-United States. 3. Maternal health services-United States. 4. Midwifery-United States. I. Title.

RG5I8.U5W34 2007

362.198'200973-dc22 2006018090

Manufactured in the United States of America

$\begin{array}{llllllllll}\text { I5 } & \text { I4 } & \text { I3 } & \text { I2 } & \text { II } & \text { IO } & 09 & 08 & 07 & 06\end{array}$

IO $\quad 9 \begin{array}{lllllllll} & 8 & 7 & 6 & 5 & 4 & 3 & 2 & \text { I }\end{array}$

The paper used in this publication meets the minimum requirements of ANSI/NISO Z39.48-1992 (R 1997)

(Permanence of Paper). 